\title{
Verb forms / constructions in the Prešov variant and the Bačka-Srem variant of the Rusyn language*
}

\author{
MIHAJLO P. FEJSA \\ Department of Ruthenian Studies, University of Novi Sad, 2 Zorana Đinđića, SRB-21000 Novi Sad \\ E-mail: fejsam@gmail.com
}

(Received: 22 May 2018; accepted: 10 August 2018)

\begin{abstract}
There are four variants of the Rusyn language: the Bačka-Srem variant (in Serbia and in Croatia), the Prešov variant (in Slovakia), the Lemko variant (in Poland), and the Transcarpathian variant (in Ukraine). The author of this paper compares the verb forms / constructions in the Bačka-Srem variant of the Rusyn language (South Rusyn / Ruthenian; pyскu $я з и к)$ and the Prešov variant of the Rusyn language (West Rusyn; русински язик) and determines the similarities and differences between them. The work essentially represents one of the rare comparisons of a language segment of the existing Rusyn language variants and the author pleads for comparing other language segments too, including the respective language segments of the Lemko variant and the Transcarpathian variant, which could lead to a wider comparative project on an international level. The comparison of the verb forms / constructions in the Bačka-Srem and the Prešov literary standard is based on contemporary grammars.
\end{abstract}

Keywords: Rusyn language, the Bačka-Srem variant, the Prešov variant, verb forms, verb constructions, conjugation

\section{Introduction}

The Grammar of the Bačka-Rusyn Speech published by Havrijil Kosteljnik in 1923 (Костельник 1975: 207-312) "has introduced and established the basic lexical, phonetic, and grammatical (morphological and syntactic) word-formation norms". From that moment, the Bačka-Srem Ruthenian speech "obtains a complete set of differential characteristics of a literary language” (Дуличенко 2009: 228).

The work on standardizing and studying the mother tongue started by Kosteljnik was continued by Nikola N. Kočiš to a significant extent. His intention was to create a normative system for school textbooks and to expand it into other spheres in which a literary language is used later. From 1965 to 1968, three grammar books were published under the title Mother Tongue, in which not only was the school material included but important normative issues were solved as well. Of course, the result of his normative activity was not the last word of standardization but the main thing was done - a normative system was created. His Grammar of the

* The paper was financed by the Ministry of Education, Science and Technological Development of the Republic of Serbia under the Research grants № 178002 (Languages and Cultures in Time and Space) and № 178017 (Discourses of Minority Languages, Literatures and Cultures in Southeast and Central Europe). 
Ruthenian Language was published in 1974 posthumously (Сегеди 2006: 249). It is important that Kočiš also published the first Orthography Rule-Book of the Ruthenian Language (Кочиш 1971) and the first dictionary, Terminology Dictionary of Serbian-Croatian-Ruthenian-Ukrainian (Кочиш 1972).

Julijan Ramač is considered to be one of the most prominent scholars in Ruthenian philology. The aforementioned Kočiš's grammars did not cover all linguistic fields, so it was necessary to write a more complete grammar of the Ruthenian language and after a decade's work Ramač's Grammar of the Ruthenian Language was published in 2002. As the author points out, it should be useful to schoolchildren and students as well as lecturers and other cultural workers (Р АмАч 2002: 3). Generally speaking, Ramač is worthy of attention because he developed the work of his predecessors, studied the linguistic fields they had not studied and systematized all of it in his grammar. In addition, he is the author of several important linguistic works, e.g. Ruthenian Lexicon (РАмач 1983), Phrase Dictionary SerbianCroatian-Ruthenian (РАмач 1987), and Practical Stylistics (РАмАч 1996) as well as the editor-in-chief of major lexicographic works: Serbian-Ruthenian Dictionary (РАмАч и др. 1995-1997) and Ruthenian-Serbian Dictionary (РАмАч и др. 2010) were published.

The Ruthenian literary standard was treated as a dialect of the Ukrainian language in Kosteljnik's and Kočiš's grammars while it was treated as a language in the full sense of the term in Ramač's grammar. The Bačka-Srem standard as a language took its place in Slavic linguistics in the 1980s, thanks to Alexander D. Duličenko who, on the basis of sociolinguistic parameters, included it in the category of Slavic literary microlanguages as a completely "distinct Slavic microlanguage" (Дуличенко 1981: 134) or as an "island Yugoslav-Ruthenian microlanguage" (Дуличенко 2009: 15). The attribute Yugoslav was appropriate at the time when there existed the country with the noun Yugoslavia in its name, which included Bačka, Srem, and Slavonia but since the Republic of Croatia and the Republic of Serbia were founded, and the Ruthenians were divided and began to live in two countries, a more appropriate attribute for the Ruthenian literary language is South Ruthenian / Rusyn; the attributes Backka-Srem and Vojvodina are also adequate but they have a narrower meaning because they suggest that the Ruthenian language is used only in Serbia. Summarizing the significance of Duličenko's scientific activity, Ramač concludes that he, among other things, "theoretically explained South Ruthenian/Rusyn microphilology as a scientific discipline" (РАмAч 2011: 26).

While the South Rusyn language did not have a multi-year break in its development, this cannot be said for the Rusyn idioms (types of languages and grammars used at a certain time or at a particular place) in the homeland, in the Carpathian region because within the framework of the Soviet Union three and a half decades (1953-1989) were administratively erased. The reason for this is that in the 1950s, for example, in Slovakia, more than 300 Rusyn schools were abruptly transformed into Ukrainian schools. The Rusyns in the Carpathian area were not even allowed to express themselves as Rusyns. "As a result of such short-sighted linguistic practices and the abrupt and administrative manner in which Ukrainian 
was introduced - all carried out during the height of Stalinist repression - the Rusyn populace reacted by sending their children to Slovak schools in neighbouring towns or by demanding Slovak instead of Ukrainian schools in their villages" (MAGOCSI 1996: 33). Such linguistic practice was based on the declaration that all East Slavs of the Carpathians, no matter how they express themselves, are Ukrainians. The declaration was made in 1924 at the Fifth Congress of the Comintern and confirmed in 1925 at the Ninth Congress of the Communist Party of Ukraine (MAGOCSI 2004: 34). Even today, there is a categorical point of view according to which "there cannot and should not be" a distinct Carpatho-Rusyn nationality since all Rusyns are only a "branch" of the Ukrainian nationality. This view is particularly widespread in Ukraine, the only country that refuses to recognize Ruthenians as a distinct people (DUBIEL-DMYTRYSZYN 2012: 41).

Only after the collapse of Comintern language practice, that is, after the socalled Velvet Revolution in 1989, the Rusyn language question was raised again. Pro-Rusyn cultural workers and scholars from Czechoslovakia (since 1993, the Czech Republic and the Republic of Slovakia), Poland, and Ukraine focused on national orientation and listed the initial goals as the official recognition of the $\mathrm{Ru}$ syn national identity, the (re)introduction of the Rusyn language into schools, the re-establishment of the Greek Catholic Church, and the reorientation of the magazine Nove Žitija from the Ukrainian identity to the Rusyn (DUBIEL-DMYTRYSZYN 2012: 41). The (re)introduction of the Rusyn language into schools required the codification of the Rusyn language. For pro-Ukrainian cultural workers and scholars, there is no Rusyn language, this is only a dialect of the Ukrainian language (Husar StruK 2014, ПАнчук 1995, МишАНич 2013).

The first Rusyn Language Congress took place in 1992 in Bardejovske Kupelji (Slovakia). It initiated a systematic work on codification on the territory of the former Carpathian Rus'. The so-called Romansch model was accepted, i.e. the participants agreed to standardize three living speeches in three regions where Rusyns live: in the Prešov region (in Slovakia), in the Lemko region (in Poland) and in the Transcarpathian region (in Ukraine) (Bačka-Srem Rusyn already existed at that time in former Yugoslavia), following the language policy of the Romansch minority in Switzerland that standardized five regional standards (Surselvan, Sutselvan, Surmerian, Puter, and Valader). ${ }^{1}$ The Rusyn literary standard in Slovakia is based on the country's two most prevalent speeches: the West Zemplin and the East Zemplin (Яьур-Плшкова 2004: 148). A few months after the First Rusyn Language Congress, at the beginning of 1993, the Rusyns in Slovakia established the Institute of the Rusyn Language and Culture in Prešov, and after two years of intensive work, preconditions for codification were created. Vasilj Jabur and Jurij Panjko made up The Rules of the Rusyn Orthography (Яьур-Панько 1994). Panjko also published The Orthographic Dictionary of the Rusyn Language (ПАнько 1994a) and the Rusyn-Russian-Ukrainian-Slovak Dictionary of Linguistic Terms

\footnotetext{
${ }^{1}$ Rumantsch / Romansh / Rhaeto-Romance: Switzerland's Fourth National Language. http:// official-swiss-national-languages.all-about-switzerland.info/rumantsch-language.html.
} 
(ПАнько 1994b). Jan Hrib published the primer and the reader for primary schools. These textbooks became the cornerstone of the codification of the Rusyn language in Slovakia, which took place in 1995 in Bratislava.

The next significant moment for the codification of the Rusyn language came in 2004. That year, in the renowned edition Modern History of the Slavic Languages of the Opole University in Poland, the fourteenth monograph dedicated to Rusyn, the youngest Slavic language, was published. The first language described in this edition is Serbian (1996), followed by Bulgarian (1997), Russian (1997), Sorbian (1998), Czech (1998), Slovak (1998), Slovenian (1998), Croatian (1998), Belarusian (1998), Macedonian (1998), Ukrainian (1999), Polish (2001), and Kashubian (2001). The editor of the monograph titled The Rusyn Language is Paul Robert Magocsi (MAGOCSI 2004). The monograph contains four variants of the Rusyn language: the Prešov variant (in Slovakia), the Lemko variant (in Poland), the Transcarpathian variant (in Ukraine), and the Vojvodina variant (in Serbia); and there are tendencies to codify a variant of the Rusyn language in Hungary as well. The South Rusyn and the Prešov Rusyn variants in the monograph were presented by Ramač and Fejsa (РАMAч 2004, ФEJCA 2004), and Jabur and Pliškova (Яьур-Плшшкова 2004, Плїшкова 2004), respectively. Scholars pay attention to the variants of the Rusyn language increasingly, no matter if one of the variants is their mother tongue or not (e.g. Kushко 2007, Тир 2010, BAPтіE 2011).

Favourable conditions were created for Bačka-Srem Rusyns when the Autonomous Province of Vojvodina gained extensive rights of self-rule under the 1974 Constitution, which defined Vojvodina as one of the subjects of the Yugoslav federation. Five of the Vojvodina's peoples were given the status of official nationalities: Serbs, Hungarians, Romanians, Slovaks, and Rusyns / Ruthenians. The Ruthenian language became one of the five official languages of the APV. For the first time it became possible to use Ruthenian language in the court, in offices on public signatures, etc. We think that the most important achievement of the Ruthenian national community in Vojvodina / Serbia is the creation of educational system from pre-school education to the highest level of education, i.e. to the Department of Ruthenian Studies in Novi Sad (ФEJCA 2010).

In the next chapter, we will present the results of the analysis of the research corpus, which is aimed to contribute to determining, on this occasion only on the basis of the verb forms / constructions, to what extent the language of Ruthenians that began to emigrate in the middle of the 18th century "into the Bačka region (and then to the neighbouring regions of Srem and Slavonia) retains the ZemlinŠariš and Spiš characteristics of the West Rusyn dialect group" (DuLichenko 2002: 263). The West Rusyn dialect group in this paper is represented by the codified Prešov variant of the Rusyn language in Slovakia.

The research corpus consists of the examples of the verb forms / constructions that are included in contemporary grammars - in the above-mentioned Grammar of the Ruthenian Language by Ramač (РАMAч 2002) and in the Grammar of the Rusyn Language by Jabur, Pliškova, and Koporova (Яьур и др. 2015). Jabur also paid considerable attention to the verb forms / constructions in his monograph Mor- 
phology and Syntax of the Rusyn Language (Яьур 2015). Magocsi and Fejsa illustrated the basic verb forms / constructions in the South Rusyn language with a few examples in the manual Let's Speak English and Rusyn (МАгочи-ФЕйСА 1997).

\section{The verb forms / constructions in the Prešov and Bačka-Srem Rusyn variants}

With regard to verb forms, Vasilj Jabur noted 12 phenomena (JABUR 1996: 58-61). In this chapter, we will compare the phenomena of the Prešov variant of the Rusyn language (PR) with the Bačka-Srem variant of the Rusyn language (BSR).

1. Infinitives usually end in -ti, e.g. čitati 'read', kupovati 'buy', siditi 'sit', vesti 'bring' (-ти, е.g. чітати, куповати, сидіти, вести) in PR and in -c, e.g. čitac, kupovac, šedzic, vesc (-u, e.g. читаu, куповаи, шедзии, веси) in BSR. A certain number of verbs end in -či $i$, e.g. peči 'bake', voloč $i$ 'carry', teči 'flow', тос̆і 'can' (е.g. печi, волочi, течі, мочі) in PR, and only one verb ends in -чи, moči 'can' (мочи), in BSR (JABUR 1996: 28, РАMAч 2002: 113).

2. As in other Slavic languages, conjugational categories are differentiated according to person, singular or plural, tense, aspect, mode, and voice in both languages.

3. Verb forms are generally constructed from the present or infinitive stem in both languages (JABUR 1996: 59).

4. Two conjugational types are distinguished in PR: the first, or the so-called $-e$ - conjugation; and the second, or the so-called $-u / i-(-i-)$ conjugation (JABUR 1996: 59). Two conjugational types are distinguished in BSR as well: the first, or the so-called - $e$ - or $-a$ - conjugation; and the second, or the so-called - $u / i-(-u / j i-)$ conjugation (PAMAY 2002: 121). These two conjugational types have been distinguished on the basis of the dominant stem vowel in the present tense conjugation. The main difference concerns the verb stems in the stem vowel $-a$-, which are expanded in PR, e.g. 1st person plural and 2nd person plural: yuma- $\epsilon$ - (čita-je-) ( $<$ 'read'); in BSR, the stem is not expanded for the present forms of these two persons of the plural and is the same as for all three present forms of the singular: чита- (čita-).

5. The forms of the present tense are created by adding a system of distinct inflections to the present stem of imperfective verbs in both languages. The inflections differ in PR and BSR. In PR, they fall into two conjugational categories, the first of which has two subcategories:

The first conjugation:

a) 1 st p. sg. $-y /-ю, 2$ nd p. sg. -еш/-єш, 3rd p. sg. -е/-є; 1st p. pl. -еме/-єме, 2 nd p. pl. -eme/-eme, 3rd p. pl. -ymb/-юmь (1st p. sg. -u/-ju, 2nd p. sg. -eš/-ješ, 3rd p. sg. -e/-je; 1st p. pl. -ете/-jеме, 2nd p. pl. -ete/-jete, 3rd p. pl. -ut'/-jut');

b) 1 st p. sg. $-\mu, 2$ nd p. sg. $-u$, 3rd p. sg. - $-m b$; 1 st p. pl. - $-м e, 2$ nd p. pl. - $-m e$, 3rd p. pl. -ymb/-ють (1st p. sg. -m, 2nd p. sg. -5 , 3rd p. sg. $-t^{\prime} ; 1$ st p. pl. -me, 2nd p. pl. -te, 3rd p. pl. -ut'/-jut'). 
The second conjugation:

1 st p. sg. $-y /-ю, 2$ nd p. sg. -uш/-iш, 3rd p. sg. -ить/-imь; 1st p. pl. -име/ -iмe, 2nd p. pl. -ume/-ime, 3rd p. pl. -ать/-яmь (1st p. sg. -u/-ju, 2nd p. sg. -iš, 3rd p. sg. -it'; 1st p. pl. -ime, 2nd p. pl. -ite, 3rd p. pl. -at'/-jat').

In BSR, the present tense is formed by adding the following endings to the imperfective verb present stem:

1st p. sg. $-\mu, 2$ nd p. sg. - $-u, 3$ rd p. sg. -Ø; 1st p. pl. - $-\mu$, , 2nd p. pl. -ue, 3rd p. pl. $-y /-\wp$ to $-a$ - and -e- imperfective verb present stems or $-a /-a$ to $-i$-imperfective

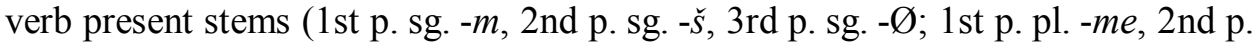
pl. $-c e, 3$ rd p. pl. $-u /-j u$ or $-a /-j a)$.

In -e- and - $i$ - present forms, the thematic vowel is dropped before the third person plural ending, and $-j$ - occurs after a vowel (and after a labial in $-i$ - present forms) (BIDwell 1966: 38), e.g. 1st p. sg. шедзим (šedzim 'I am sitting / I sit'), 3rd p. pl. шедза (šedza 'They are sitting/They sit'), 1st p. sg. любим (ljubim 'I love'), 3rd p. pl. любя (ljubja 'They love').

We notice that the 1st p. sg. form in BSR is similar to the 1st p. sg. form in subcategory $b$ ) of the first conjugation in PR. The main difference concerns the 3 rd p. sg. and the $3 r d$ p. pl. forms since they are characterized by final $-m b\left(-t^{\prime}\right)$ in PR.

6. The future tense is created in two ways depending on aspect. The simple form is formed by adding the same endings as for the present tense to the perfective verb present stems, e.g. винєшем (vinješem 'I'll carry out'). The compound form is formed by combining the future tense forms of the auxiliary verb бolmu (PR) / буи (BSR) (byti / buc 'be') - будy, будеш, буде, будеме, будете, будуть (PR) / будзем, будзеш, будзе, будземе, будзеие, буду (BSR) (budu, budeš, bude, budete, budut'/budzem, budzeš, budze, budzeme, budzece, budu 'shall, will') and the infinitive of the imperfective verbs, e.g. (я) буду читати (PR) / (я) будзем чumau (BSR) (ja budu čitati / ja budzem čitac 'I shall write'). The subject pronoun may be omitted in both Rusyn variants.

7. The past tense is created in two ways both in PR and in BSR.

a) The simple past tense form is formed by adding the endings $-\beta(-v$; for the masculine gender sg.), -ла (-la; for the feminine gender sg.), -ло (-lo; for the neuter gender sg.), $-л и$ ( $-l i$; for all three genders in the plural) in PR, and $-л(-l$; for the masculine gender sg.), -ла (-la; for the feminine gender sg.), -ло (-lo; for the neuter gender sg.), -ли (-li; for all three genders in the plural; in the Kucura speech, almost obsolete, the ending -лï, i.e. -lji) in BSR to the infinitive stem. In this case, the subject pronoun may be omitted, е.g. читав, чітала, чітало, чітали in PR, and читал, читала, читало, читали in BSR.

The main difference is in the ending for the masculine gender sg. ( $-v$ in PR : $-l$ in BSR). This ending may be omitted in both languages, e.g. виз 'he drove', нïc 'he carried', миг 'he could' (JABUR 1996: 68) - вез, нес, мог (viz, njis, mih : vez, njes, moh).

In the so-called $-u / \ddot{i}-(-i / j i-)$ conjugation, the verbs change thematic $-i$ to $-e$ in BSR (e.g. досли/dojeli 'they milked'), which is not the case in PR (e.g. доӥли/ dojili). 
b) The compound past tense forms are formed by combining the simple past tense forms and the forms of the auxiliary verb бoımu (byti) for the first and second person sg. and pl. ( $\epsilon$, $\epsilon с b, \varnothing$, сьме, сьте, Ø) in PR and (сом, ши, Ø, зме, cue, Ø) in BSR (jem, jes', s'me, s'te; som, ši, zme, sce).

The main difference is that the forms of the auxiliary verb бolmu in PR can be abbreviated in the feminine and neuter gender and added as suffixes to the simple past tense forms, е.g. читала єм > читалам 'I read' (citala jem > čitalam); the forms of the auxiliary verb бyu in BSR cannot be abbreviated in the feminine gender sg. and the neuter gender sg., e.g. читала сом (čitala som).

8. The imperative forms for the second person singular and for the first and second person plural are formed from the present stem. Generally speaking, the forms for the second person singular are formed by adding the imperative formant $-\breve{u}$ - (-j-) to present stems ending in a vowel, e.g. читай 'read', спивай 'sing', знай 'know' (čitaj, spivaj, znaj) in PR, and читай, шпивай, знай (čitaj, špivaj, znaj) in BSR, by adding the imperative formant $-u-(-i-)$ to present stems ending in a consonant cluster, e.g. бухни 'strike', выпни 'put up' (buchni, vypni) (JABUR 1996: 60) or бухний, выпний (buchnij, vурпіj) (Яьур 2015: 70) in PR, and бухнї, випнї (buchnji, vipnji) in BSR, and by adding the imperative formant - $\varnothing$ to present stems in other cases (as to the verbs with stems ending in unpaired soft or hard consonants: пиш 'write', кyn 'buy', роб 'work', i.e. piš, kup, rob in both languages).

The verbs with stems ending in a soft or a hard paired consonant have an imperative form without any inflexion and with a softened final consonant in PR, e.g. говорь 'speak up', ударь 'hit', принесь 'bring' (hovor', udar', prines'); in BSR, besides гутор, вдер, принєш (hutor, vder, prinješ) there exist several imperative forms ending in softened final consonant, e.g. стань 'stand up', запаль 'burn' (stan', zapal'). To form the imperative forms in BSR, the present stems with thematic $-i$ - or $-e$ - drop these vowels and the present stems in consonants $\partial$ and $m$ $(d, t)$ change these consonants in $\partial 3$ and $u(d z, c)$.

The form for the first person plural is formed by adding the suffix - - e (-me) to the form for the second person singular in both languages, e.g. спивайме 'let's sing', встаньме 'let's stand up', пишме 'let's write' (spivajme, vstanjme, pišme) in PR and шпивайме, станьме, пишме (г̌pivajme, stanjme, pišme) in BSR.

The form for the second person plural is formed by adding the suffix -me (-te) in PR and the suffix -ue (-ce) to the form for the second person singular in both languages, e.g. читайme 'read', рижте 'cup', дайme 'give' (čitajte, rižte, dajte) in PR and читайuе, режие, дайие (čitajce, režce, dajce) in BSR.

The forms for the third person singular and plural are compound and formed by combining няци (njaj) in PR, i.e. най (naj) in BSR, and the forms for the third person singular and plural of the present tense, e.g. няй встане - няй встануть 'let him/her stand up - let them stand up', няй несе - няй несуть 'let him/her carry - let them carry', няй читать - няй читають 'let him / her read - let them read' (njaj vstane - njaj vstanut', njaj nese - njaj nesut', njaj čitat' - njaj čitajut') in PR, най станє - най станю, най нєше - най нєшу, най чита - най читаю (naj stanje - naj stanju, naj nješe - naj nješu, naj čita - naj čitaju) in BSR. 
9. We distinguish two types of conditional in PR and BSR - present and past.

a) The present conditional is formed by adding the particle $\sigma b l$ in PR, i.e. $\sigma u$ in BSR $(b y / b i)$, either before or after the simple forms of the past tense, which depend on gender. In cases when a subject pronoun is not uttered, the forms of the auxiliary verb бolmu (byti) for the first and second person sg. and pl. ( $\epsilon M, \epsilon c b, \varnothing$, сьме, сьте, Ø) in PR and (сом, ши, Ø, зме, сие, Ø) in BSR (jem, jes', s'me, s'te; som, si $i$, zme, sce) are used. They are blended with $\sigma b l$ for the first and second person singular in PR (бblм, бblcb; bym, bys'); the forms of the auxiliary verb бyu are blended with $\sigma u$ for the first and second person singular and plural in BSR (бuм, биш, бизме, бисие; bim, biš, bizme, bisce). For example, я бы написав, ти бы написала, etc. in PR and я би написал, ти би написала, etc. in BSR.

b) The past conditional is formed by adding the appropriate gender of the past tense forms of the auxiliary verb быти, i.e. буи (быв, была, было, были, i.e. бул, була, було, були; byv, byla, bylo, byli, i.e. bul, bula, bulo, buli) to both constructions of the present conditional. For example, я бы быв написав, ти бы была написала, etc. in PR and я би бул написал, ти би була написала, etc. in BSR.

10. As far as the category of aspect is concerned, two aspectual modes can be distinguished: the perfective / totive and the imperfective / non-totive mode. The first mode conveys the realization of a verb situation as a whole; the second mode conveys the realization of a verb situation as a structure, comprising several meanings concerning structure such as "process", "on-going activity", "duration", "unlimitedness", "incompleteness", etc. (FeJsA 2005: 308). The two modes are mostly distinguished in one of the following three ways; a) the perfective has a prefix, the imperfective does not; $b$ ) the perfective may have a change in the form of the root; c) the imperfective will have a special suffix, while the perfective does not (МАГочи-ФЕйСА 1997: 110). Generally speaking, the aspect modes are formed in a manner similar to other Slavic languages.

11. PR has two forms of verbal adverbs: present verbal adverbs and past verbal adverbs. The present verbal adverbs (JABUR 1996: 60-61) or the present participles (BIDWELL 1966: 38) are formed by adding the ending - $-i(-c ̌ i)$ to the forms for the third person plural of the present tense, e.g. piжyчi 'cutting', чітаючi 'reading', клячачi 'kneeling', сидячi 'sitting' (rižuс̌i, čitajuči, kljačači, sidjači). The past verbal adverbs are formed from the infinitive stem and the ending -вши (in rare cases, -uи) (-vši or -ši ), e.g. написавши 'after writing', увидівши 'after seeing', прочітавщи 'after reading' (napisavši, uvidivši, pročitavši) (cf. BIDWELL 1966: 41).

BSR has only the present verbal adverbs. They are formed by adding the ending -u $u(-c i)$ to the forms for the third person plural of the present tense, e.g. peжуци, читаюии, клєчаџи, шедзащи (režuci, с̌itajuci, klječaci, šedzaci).

12. $P R$ has three productive forms of verbal adjectives (the present active verbal adjective, the past active verbal adjective, the past passive verbal adjective); a forth form (the present passive verbal adjective) is very rare and not productive (BIDWELL 1966: 41). The present active verbal adjective is formed by adding the

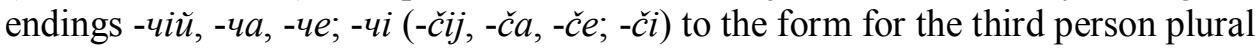


of the present tense, e.g. говорячій 'a man who is fond of talking, talkative', чimaючій 'a man who is fond of reading', пишучій 'a man who is fond of writing', etc. (čitajučij, hovorjačij, pišučij). The past active verbal adjective is formed from the infinitive stem and the endings -вшый, -вша, -вше; -вшы or in rare cases -шыьй, $-u a,-u e ;-u b l(-v \check{s} y j,-v \check{s} a,-v \check{s} e ;-v \check{s} y$ or $-\check{s} y j,-\check{s} a,-\check{s} e ;-\check{s} y)$, чimaвublü 'a man who was fond of reading', писавшыци 'a man who was fond of writing', укравшый 'a man who is was fond of stealing' (čitavšyj, pisavšyj, ukravšij). The past passive verbal adjective (or the past participles; BIDWELL 1966: 39) is formed from the infinitive stem and the endings $-н b l \tilde{u},-н a,-н e ;-H b l$ (before these endings the thematic $-u$-, i.e. $-i-$, is replaced by $-e-$ ) and in several cases (for the verbs with stems in suffix - $-н y$-, i.e. $-n u$-, for one-syllable verbs, etc.) the endings -mbiŭ, -ma, -me; -mbl, е.g. прочітаный 'read', договореный 'agreed', битый 'beaten' (pročitanyj, dohovorenyj, bityj). The present passive verbal adjective is an unproductive form preserved only in written texts of religious character. It is formed from the infinitive stem and the endings -мblü, -мa, -ме; -мbl, e.g. видимиц 'that can be seen, visible', любимий 'that can be loved, lovable', носимий 'that can be carried, portable' (vidimyj, ljubimyj, nosimyj) (JABUR 1996: 61).

BSR has only the past passive verbal adjective. It is formed from the infinitive stem and the endings $-н u,-н а,-н е ; ~-н u ~(-n i,-n a,-n e ;-n i)$ (before these endings, the thematic $-u$-, i.e. $-i$-, is replaced by $-e-$ ) and in several cases (for verbs with stems in suffix $-\mu y$-, i.e. $-n u$-, for one-syllable verbs, for prefixed one-syllable verbs, and for several verbs with the infinitive stem in $-u$-, i.e. $-i-$; РАМАЧ 2002 : 128) the endings -mu, -ma, -me; -mu (-ti, -ta, -te; -ti), e.g. пречитани 'read', догварени 'agreed', бити 'beaten' (prečitani, dohvareni, biti).

The select phenomena deserve a much larger comparative descriptive study.

\section{Conclusion}

There are four variants of the Rusyn language: the Bačka-Srem variant (in Serbia and Croatia), the Prešov variant (in Slovakia), the Lemko variant (in Poland), and the Transcarpathian variant (in Ukraine). The author of this paper compares the verb forms / constructions in the Bačka-Srem variant of the Rusyn language (South Rusyn/Ruthenian) and the Prešov variant of the Rusyn language (West Rusyn) and determines the similarities and differences between them.

The comparison of the verb forms / constructions has established more similarities than differences between two compared literary standards in this linguistic segment and it can be concluded that a part of the above-mentioned Duličenko's statement (DULICHENKo 2002: 263) has been confirmed, i.e. that the language of the Rusyns / Ruthenians in Bačka, Srem, and Slavonia retains the Zemplin characteristics of the West Rusyn dialect group to a significant extent. Wider comparisons are needed in order to confirm the retention of the Šariš and Spiš characteristics.

The comparison of the verb forms / constructions made in this paper represents a comparison of only one of the linguistic segments of two variants of the Rusyn 
language. We hope that this work will stimulate other authors to compare other language segments in other, if not all language variants of the Rusyn language. The fact that there exist philological centres in Novi Sad (Serbia), Prešov (Slovakia), Kraków (Poland), Budapest (Hungary), Užhorod (Ukraine), and Toronto (Canada) could enable to organize international comparative projects on a wider scale. The comparison of the variants of the Rusyn language and the neighbouring Slavic languages could illuminate all the linguistic processes, and, in connection with this, language description could be enriched and orthography could be improved.

The development of Rusyn comparative studies could also facilitate communication among the speakers of the variants concerned to a great extent. This is important because it was noted that "each of four literary varieties of the Rusyn language is the result of sociolinguistic factors and the varieties differ from each other significantly" (Тир 2010: 56).

In addition, emphasizing the similarities and differences between the Prešov and Bačka-Srem verb forms / constructions, the author believes that this comparative work will also enable to understand and to master the course material at the Department of Rusyn Studies, where students have the opportunity to study the Rusyn variants.

\section{References}

BAPTIE 2011 = BAPTIE Gavin: Issues in Rusyn Language Standardisation. http://theses.gla. ac.uk/2781/1/2011BaptieMPhil-1.pdf.

Bidwell 1966 = Bidwell Charles E. The Language of the Bačka Ruthenians in Yugoslavia. The Slavic and East European Journal 10 (1966): 32-45.

DuBIEL-DMYTRYSZYN 2012 = DuBIEL-DMYTRYSZYN Sebastian: The Rusyns of Slovakia. Our Europe. Ethnography - Ethnology - Anthropology of Culture 1 (2012): 39-44.

Dulichenko 2002 = Dulichenko A. D. Vojvodina. In: Magocsi P. R., Pop I. I. (ed.) Encyclopedia of Rusyn History and Culture. Toronto: University of Toronto Press, 2002. 263.

FeJSA 2005 = FeJSA Mihajlo: Vreme $i$ vid u rusinskom i engleskom jeziku. Novi Sad: Filozofski fakultet, Odsek za rusinistiku - IK Prometej, 2005.

HUSAR STRUK 2014 = HUSAR STRUK Danylo: Mykola Mushynka. In: Internet Encyclopedia of Ukraine. http://www.encyclopediaofukraine.com/display.asp?\%20linkpath=pages\% 5CM\%5CU\%5CMushynkaMykola.htm.

JABUR 1996 = JABUR Vasyl': Select Aspects of the Rusyn Language Norm in Slovakia. In: Magocsi P. R. (ed.) A New Slavic Language is Born. New York: Columbia University Press, 1996. 49-62.

KusнKo 2007 = KushKo Nadiya: Literary Standards of the Rusyn Language. The Historical Context and Contemporary Situation. The Slavic and East European Journal 51 (2007): 111-132.

Magocsi $1996=$ Magocsi P. R. The Rusyn Language Question Revisited. In: MAGOCsI P. R. (ed.) A New Slavic Language Is Born. New York: Columbia University Press, 1996. 19-47.

Magocsi $2004=$ Magocsi P. R. (red.) Русиньскый язык. Opole: Uniwersytet Opolski Instytut Filologii Polskej, 2004. 
Дуличенко 1981 = Дуличенко А. Д. Русинский язык. В кн.: Супрун А. Е. и др. (ред.) Введение в славянскую филологию. Минск: «Вышейшая школа», 1981. 132-134.

Дуличенко 2009 = Дуличенко А. Д. Jugoslavo Ruthenica II. Роботи з рускей филололиї и историї. Нови Сад: Филозофски факултет и НВУ Руске слово, 2009.

КостЕЛЬНик 1975 = КостеЛЬник Гавриїл: Проза. Нови Сад: Руске слово, 1975.

Кочиш 1971 = Кочиш Микола М. Правопис руского язика. Нови Сад: Покраїнски завод за видаванє учебнїкох, 1971.

Кочиш 1972 = Кочиш Микола М. Приручни терминологийни словнїк сербскогрватско-руско-украӥнски. Нови Сад: Руске слово, 1972.

МАґОЧИ-ФЕЙСА 1997 = МАґОЧИ П. Р., ФЕЙСА М. Let's Speak English and Rusyn / Бешедуйме по антлийски и по руски. Нови Сад: Руске слово, 1997.

МишАнич 2013 = МишАнич Олекса: Політичне русинство: історія і сучасність. Ідейні джерела закарпатського регіонального сепаратизму. В кн.: Скрипник Г. (ред.) Украӥнці-русини: етнолінгвістичні та етнокультурні процеси в історичному розвитку. Київ: Інститут мистецтвознавства, фольклористики та етнології ім. М. Т. Рильського - Міжнародна асоціація україністів, 2013. 9-62.

ПАнчук 1995 = ПАнчук Май: Політичне русинство в Україні. http://itopys.org.ua/ rizne/panchuk.htm.

ПАнько 1994а = ПАнько Юрий: Орфотрафічный словник русиньского языка. Пряшів: Русиньска оброда, Інштітут русиньского языка и културы, 1994.

ПАнько 1994b = ПАнько Юрий: Русиньско-русько-украӥньско-словеньскый словник лінгвістічных термінів. Пряшів: Русиньска оброда, Інштітут русиньского языка и културы, 1994.

ПлїшковА 2004 = ПлїшковА Анна: Соціолінгвістічный аспект: Пряшівска Русь. In: MAgOCSI 2004: 373-383.

РАМАч 1983 = РАМАч Юлиян: Руска лексика. Нови Сад: Филозофски факултет, Институт за педагогию, Катедра за руски язик и литературу, 1983.

РАМАч 1987 = РАМАч Юлиян: Фразеолошки речник: српскохрватско-русински. Нови Сад: Филозофски факултет, Завод за издавање уџбеника, 1987.

РАМАч 1996 = РАМАч Юлиян: Практична стилистика. Нови Сад: Руске слово, 1996.

РАМАч 2002 = РАМАч Юлиян: Граматика руского язика. Београд: Завод за уџбенике и наставна средства, 2002.

РАMАч 2004 = РАМАч Юлиян: Литературни язик: Войводина. In: MAGOCsi 2004: 277304.

РАмАч 2011 = РАмАч Юлиян: Проф. др. Александер Д. Дуличенко и руска (южноруска) микрофилология. В кн.: АБисогомян И. В. (ред.) Лингвокультурное пространство современной Европы через призму мальх и больших языков. Тарту: Тартуский университет, Кафедра славянской филологии, 2011. 25-32.

РАМАЧ и др. 1995-1997 = РАМАЧ Юлиян и др. Српско-русински речник / Сербско-руски словнїк I-II. Београд: Завод за учебнїки и наставни средства - Нови Сад: Филозофски факултет, Катедра за руски язик и литературу, Дружтво за руски язик и литературу, 1995-1997.

РАмАч и др. 2010 = РАмАч Юлиян и др. Руско-сербски словнїк / Русинско-српски речник. Нови Сад: Филозофски факултет, Катедра за руски язик и литературу, Завод за културу войводянских Руснацох, 2010.

СеГЕДИ 2006 = СЕГЕДИ Ксения: Русинисти-Лингвисти. In: ФЕЙСА М. (ред.) Русини / Pуснащи / Ruthenians (1745-2005) I. Нови Сад: Филозофски факултет, Одсек за русинистику, ИК Прометеј-КПД ДОК, 2006. 248-252. 
Тир 2010 = Тир Михал: Еуген Паулини о руским / русинским язику. Studia Ruthenica 15 (2010): 55-58.

ФЕЈСА 2004 = ФЕйСА Михайло: Социолингвистични аспект руского язика: ВойводиHa. In: MAGOCSI 2004: 373-383.

ФеЈСА 2010 = ФеЈСА Михајло: Нова Србија и њена русинска мањина / Нова Сербия и єй руска меншина / The New Serbia and Its Ruthenian Minority. Нови Сад: ИК Прометеј-КПД ДОК, 2010.

Яьур 2015 = Яьур Василь: Морфология и синтаксис русиньского язика. Пряшів: Пряшівска універзіта, Інштітут русиньского языка и културы, 2015.

Яьур и др. 2015 = Яьур Василь и др. Граматика русиньского языка. Пряшів: Пряшівска універзіта, Інштітут русиньского языка и култури, 2015.

Яьур-ПАнькО 1994 = ЯьУр Василь, ПАнько Юрій: Правила русиньского правопису. Пряшів: Русиньска оброда, Інштітут русиньского языка и културы, 1994.

Яьур-ПлшшковА 2004 = ЯБур Василь, ПлшшовА Анна: Літературный язык: Пряшівска Русь. In: MAGOCsi 2004: 147-209. 